\title{
INFLUENCE OF DIFFERENT EXTRUSION TEMPERATURES ON THE STABILITY OF ELLAGIC ACID FROM RASPBERRY SEEDS
}

\author{
Boško D. Marić*, Marija I. Bodroža-Solarov, Nebojša M. Ilić, Jovana S. Kojić, Jelena A. Krulj \\ University of Novi Sad, Institute of Food Technology, 21000 Novi Sad, \\ Bulevar cara Lazara 1, Serbia
}

\author{
${ }^{*}$ Corresponding author: \\ Phone: +381642944042 \\ E-mail address: bosko.maric@fins.uns.ac.rs
}

\begin{abstract}
Production of raspberry products leaves large amounts of seeds which are considered as by-product or waste. These seeds are rich source of ellagic acid and about $88 \%$ of the total ellagic acid content in raspberries comes from the seeds.

This study investigates the influence of extrusion process at different temperatures on the content of ellagic acid in "Willamette" raspberry seeds. The extrusion was performed on a Brabender singlescrew laboratory extruder and at three temperature regimes: 140,160 and $200^{\circ} \mathrm{C}$. HPLC/DAD analysis was used to determine and quantify the content of ellagic acid in the extruded samples. Ellagic acid content was quantified by calculation using a calibration curve established from standard ellagic acid.

The content of ellagic acid in raspberry seeds was found to be $286.54 \mu \mathrm{g} / \mathrm{g}$. Use of different extrusion temperatures did not have any impact on the stability of ellagic acid from „Willamete“ raspberry seeds, i.e. did not make signifficant diferences in the content of the ellagic acid. These findings indicated that raspberry seeds may be suitable for the high temperature food processing.
\end{abstract}

Key words: extrusion, raspberry seeds, ellagic acid, corn grits, value-added product

\section{INTRODUCTION}

Serbia is one of the largest producers of raspberries with export at about 78000 tons of fresh raspberries in 2011 (Dimić et al., 2012). Production of raspberry products, such as jams, juices, concentrates leaves large amounts of raspberry seeds which are under-exploited or wasted (Couto et al., 2008). The berry seed material removed as a waste by-product contains health-beneficial, bioactive compounds (Nile et al., 2014), which are also known as natural antioxidants (Szajdek et al., 2008; Van Hoed et al., 2011).
Raspberry seeds contain a lot of antioxidants such as phenols, flavonoids, antocyanins, vitamins, etc. (Rios de Souza et al., 2014). Godjevac et al. (2009), found that raspberry seeds contain a lot of polyphenolic compounds such as ellagic acid, gallic acid, procyanidin dimer, sanguiin, roshenin, and some others (Godjevac et al., 2009). Previous studies reported that raspberry seeds contain about $87.8 \%$ of the total ellagic acid present in raspberries (Daniel et al., 1989). Ellagic acid is found in raspberries in three dif- 
ferent forms: as ellagitannins, as free ellagic acid and as ellagic acid glycosides (Zafrilla et al., 2001).

Different studies have shown that ellagic acid has antimicrobial, antimutagenic, antioxidant and anti-inflammatory properties (Khanduja et al., 1999; Wang et al., 2000; Mullen et al., 2002; Kähkönen et al., 2001; Puupponen-Pimiä et al., 2001).

One of the most important functions of ellagic acid is the ability to "adjust" cell physiology on biochemical, physiological and molecular level. This is the result of its phytophenolic structure, which has very similar biological effect as signal molecules, and can influence behavior of genes that activate and inactivate proteins and enzymes (Mates et al., 1999).

Due to the phenol ring and hydroxyl groups, ellagic acid is very effective antioxidant as it has the ability to inhibit the oxidative free radical reactions with vital biomolecules (Rice-Evans et al., 1997).

Also, the antioxidant properties of ellagic acid prevent the damage caused by oxidation of the DNA, which proved to be important in the prevention of some types of cancer and, in addition, ellagic acid prevents the carcinogenic substances to be incorporated into DNA, and thus exerts its antimutagenic properties (Halliwell et al., 1999; Teel et al., 1986).

One of the most important effects of ellagic acid is the anticancer effect and one of the main reasons for the anticancer effect is modulation of the toxin metabolism, and prevention of carcinogenesis induced by these compounds (Mitscher et al., 1996; Zhang et al., 1993; Seeram et al., 2006).

Ellagic acid also inhibits mutagenesis induced by aflatoxin B1 (Soni et al., 1997). Also, ellagic acid has hepatoprotective cha-racteristics. It inhibits the effect of $\mathrm{CCl}_{4}$, decontaminates the bloodstream (Bravo et al., 1998; Singh et al., 1999), reduces the effect of alpha-amylase and alpha-glucosidase, and prevents diabetic conditions (Valdimarsdottir et al., 2003).
Extrusion cooking is one of the most important food processing technologies, and over the years, it has become the major processing method for food and feed industries (Brennan et al. 2011).

Extrusion process has been used to produce pasta products and ready to eat breakfast cereals, baby foods, snack foods, texturized vegetable protein, pet foods, dried soups and dry beverage mixes (Singh et al. 2010).

Also, it improves digestibility and nutrients bioavailability compared to conventional cooking. In addition to these properties, extrusion cooking is preferred over conventional cooking techniques because of its ability to develop range of products with distinct textural advantages including expansion, crispiness and general mouthfeel, being versatile, high productivity, low operating costs, energy efficiency and shorter cooking times (Brennan et al., 2011).

The main objective of this study was to investigate the stability of ellagic acid from "Willamette" raspberry seeds through the extrusion process.

\section{MATERIAL AND METHODS}

\section{Materials}

Corn grits and milled "Willamette" raspberry seeds were used for this study. "Willamette" raspberry seeds were milled on a laboratory mill "Glen Mills, C/11/1, Clifton, NJ, 07012" to granulation of 150 $\mu \mathrm{m}$, and mixed with corn grits so that the ratio was $10 \%$ of the seed and $90 \%$ of the grits.

The extract of this mixture was analyzed on the HPLC to quantify the amount of ellagic acid. Prior to the extrusion, the moisture content of the mixture was set to $18 \%$. After that, HPLC method was used to determine ellagic acid content in the extruded products.

\section{Extrusion process}

A single-screw laboratory extruder (Model GNF 1014/2, Type 110513, Brabender, Germany) was used for the extrusion process. The diameter of the die was 2 
$\mathrm{mm}$. The temperature of the feeding zone was $50{ }^{\circ} \mathrm{C}$, the metering zone was adjusted to $100{ }^{\circ} \mathrm{C}$, and the die zone was adjusted to three temperatures: $140{ }^{\circ} \mathrm{C}$, $160{ }^{\circ} \mathrm{C}$ and $200{ }^{\circ} \mathrm{C}$ throughout the process.

The extruder was capable of a screw speed ranging from $0-250 \mathrm{rpm}$, so the screw speed was adjusted to $150 \mathrm{rpm}$ for the appropriate treatment. Once the processing was completed, the extrudates were stored in cool and dry place prior to further analyses.

\section{HPLC/DAD analysis of ellagic acid}

Samples were prepared as follows: the samples were homogenized and aliquots of $1.5 \mathrm{~g}$ were weighed and transferred into a $100 \mathrm{ml}$ Erlenmeyer flask and diluted in $40 \mathrm{ml}$ of $70 \%$ aqueous ethanol. The mixtures were ultrasonicated for 10 minutes. Then, they were filtered, made up to $50 \mathrm{ml}$ with ethanol and ultrasonicated for another 10 minutes.

Before quantification by HPLC-DAD, the samples were filtered through a $0.45 \mu \mathrm{m}$ membrane filter. Samples were analyzed using an Agilent 1260 series HPLC (Agilent Technologies, Santa Clara, CA, USA), using C18 column $(4.6 \mathrm{~mm} \times 50 \mathrm{~mm}$, $1.8 \mu \mathrm{m}$ particles).

Injection volume was $5 \mu \mathrm{l}$ and the temperature was at $30^{\circ} \mathrm{C}$. Solvent $A$ was $1 \%$ formic acid and solvent $B$ was acetonitrile. The used gradient was as follows: $0-10 \mathrm{~min}, 10 \%$ of $B$ in $A ; 10-25$ min, $15-$ $50 \%$ of $B$ in $A ; 25-30$ min, $50-80 \%$ of $B$ in $A ; 30-35$ min, $10 \%$ of $B$ in $A$.

In the tested raspberry samples, good purity and separation were achieved using this gradient at flow rate $0.5 \mathrm{~mL} / \mathrm{min}$. The HPLC equipment was used with a diode array detector (DAD). Ultraviolet-visible spectra (ranging from 190 to $540 \mathrm{~nm}$ ) were recorded for all peaks. Triplicate analyses were performed for each sample.

Ellagic acid was detected at $260 \mathrm{~nm}$, and identified according to peak retention time and UV/Vis spectra, which were compared with those of the standard. The quantities of ellagic acid were based on peak areas, and expressed as $\mathrm{mg} / \mathrm{g}$.

\section{Statistical analysis}

Statistica 10.0 Software (Statsoft Inc., 2010, Tulsa, Oklahoma) was used for statistical data processing using one-way ANOVA. The comparison of mean values was performed by Tukey- test. Differences were considered significant if $\mathrm{P}<0.05$.

\section{RESULTS AND DISCUSSION}

HPLC/DAD analysis was performed to determine potential ellagic acid content in pure corn grits, and the result was negative. Results of HPLC/DAD analysis of the ellagic acid content in raspberry seeds, corn grits and non-extruded sample wich contain $10 \%$ of raspberry seeds in corn grits are shown in Table 1.

Results of HPLC analysis of the extruded products are shown in Table 2. The results show that the concentration of the ellagic acid in samples extruded at $140{ }^{\circ} \mathrm{C}$ is $7.585 \mu \mathrm{g} / \mathrm{g}$, in samples extruded at $160{ }^{\circ} \mathrm{C}$ is $5.533 \mu \mathrm{g} / \mathrm{g}$, and in samples extruded at $200{ }^{\circ} \mathrm{C}$ is $6.618 \mu \mathrm{g} / \mathrm{g}$.

Statistical analysis showed that there were no significant differences among the mean contents of ellagic acid. So it can be concluded that extrusion temperature does not have significant influence on ellagic acid content in extruded products.

Additionally, it can be seen that the ellagic acid in extruded products is very stable and it was not degraded, which is in consistence with previous research of $\mathrm{Li}$ et al. (2013).

Figures 1 and 2 show peaks of ellagic acid in the samples extruded at $200{ }^{\circ} \mathrm{C}$ and in the sample of raspberry seeds. Chromatograms of ellagic acid in the samples extruded at 140 and $160^{\circ} \mathrm{C}$ were similar to that in Figure 1.

Retention times for the sample extruded at $140{ }^{\circ} \mathrm{C}$ was $17.938 \mathrm{~min}$ whereas for the sample extruded at $160{ }^{\circ} \mathrm{C}$, the retention time was $17.944 \mathrm{~min}$. The sample extruded at $200{ }^{\circ} \mathrm{C}$ has retention time at $17.956 \mathrm{~min}$. 
The retention time of ellagic acid in raspberry seeds was $18.041 \mathrm{~min}$, and the retention time of non-extruded sample with $10 \%$ of raspberry seeds in corn grits was
17.942 min. Positions of signals were confirmed using analytical standard of the ellagic acid.

\section{Table 1.}

Concentration of ellagic acid in raspberry seeds, corn grits and mix of $10 \%$ raspberry seeds in corn grits

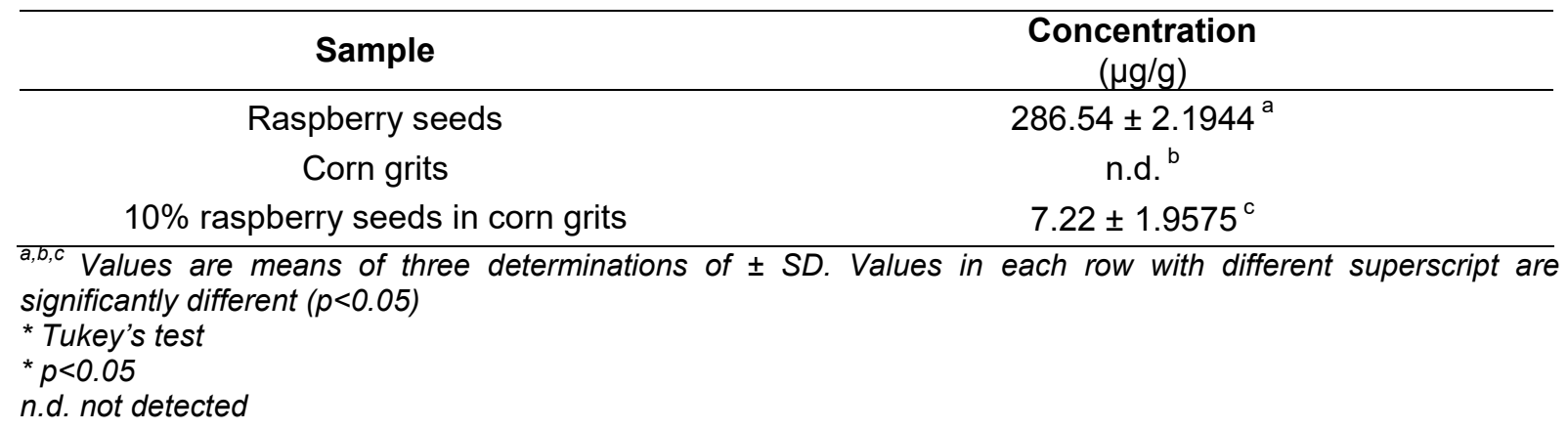

\section{Table 2.}

Concentration of ellagic acid in the products extruded at different temperatures

\begin{tabular}{lc}
\hline Temperature $\left({ }^{\circ} \mathrm{C}\right)$ & $\begin{array}{c}\text { Concentration } \\
(\mu \mathrm{g} / \mathrm{g})\end{array}$ \\
\hline 140 & $7.585 \pm 2.3335^{\mathrm{a}}$ \\
160 & $5.533 \pm 2.2368^{\mathrm{a}}$ \\
200 & $6.618 \pm 2.1053^{\mathrm{a}}$ \\
\hline${ }^{\mathrm{a}}$ Values are means of three determinations of $\pm S D$. Values with the same superscript are not significantly \\
different $(p<0.05)$ \\
${ }^{*}$ Tukey's test \\
${ }^{*} p<0.05$
\end{tabular}

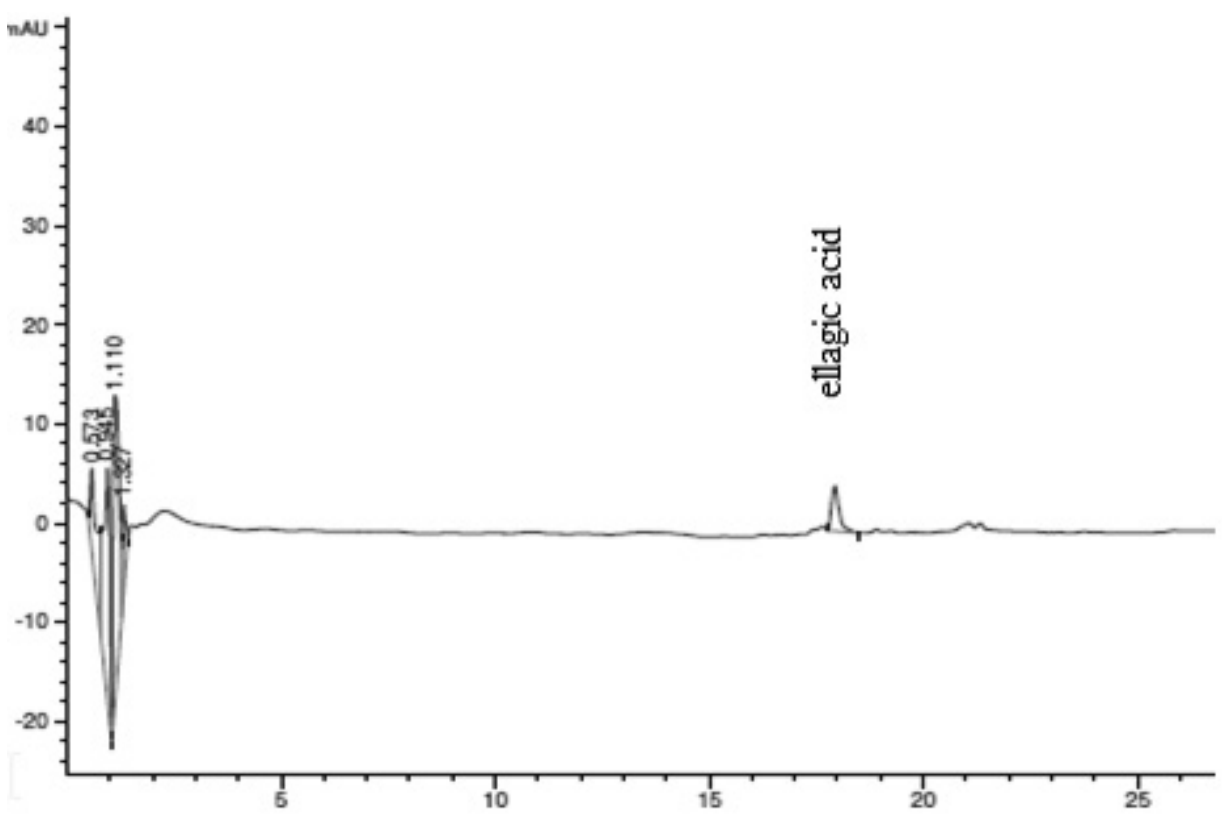

Figure 1. Chromatogram of ellagic acid extracted from the sample extruded at $200^{\circ} \mathrm{C}$ 


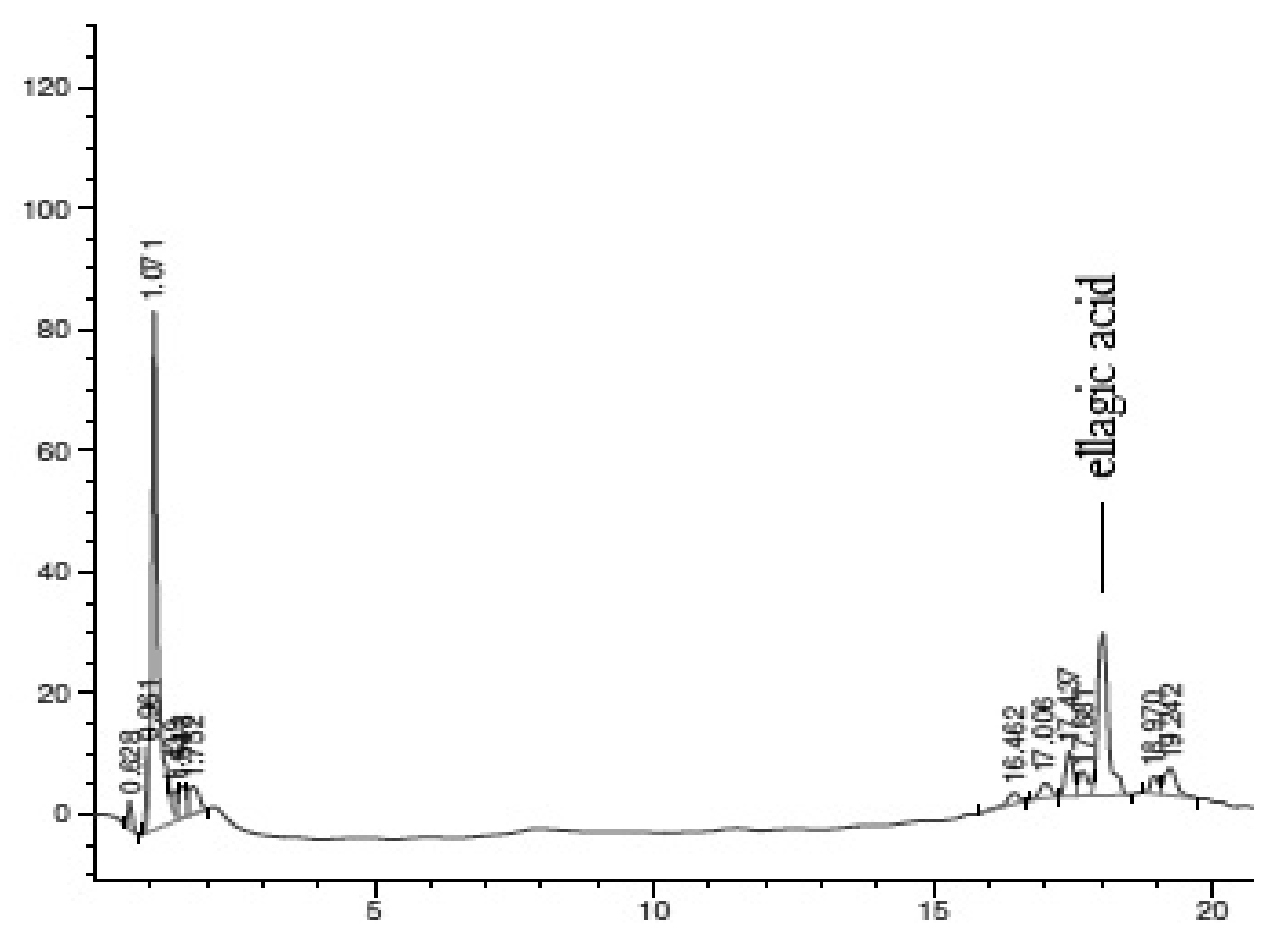

Figure 2. Chromatogram of ellagic acid extracted from raspberry seeds

\section{CONCLUSIONS}

Our study found that the raspberry seeds were signifficant source of ellagic acid. The amount of ellagic acid found in „Willamette" raspberry seeds was 286.54 $\mu \mathrm{g} / \mathrm{g}$.

It was established that ellagic acid was stable up to $200{ }^{\circ} \mathrm{C}$ and no signifficant differences in ellagic acid content were found in the non-extruded samples and samples extruded at different temperatures, so raspberry seeds can be implemented in food products requiring higher temperatures during processing.

\section{ACKNOWLEDGEMENTS}

This work is the result of research from the Project III46005 financed by the Ministry of Education, Science and Technological Development, Republic of Serbia.

\section{REFERENCES}

1. Bravo, L. (1998). Polyphenols: Chemistry, dietary sources, metabolism, and nutritional significance. Nutrition Reviews, 56, 317-333.
2. Brennan C., Brennan M., Derbyshire, E., Tiwari, B. (2011). Effects of extrusion on the polyphenols, vitamins and antioxidant activity of foods. Trends in Food Science and Technology, 22, 570-575.

3. Couto, S.R. (2008). Exploitation of biological wastes for the production of valueadded products under solid-state fermentation conditions. Biotechnology Journal, 3 , 859-870.

4. Daniel, E.M., Krupnick, A.S., Heur, Y.H., Blinzler, J.A., Nims, R.W., Stoner, G.D. (1989). Extraction, stability, and quantitation of ellagic acid in various fruits and nuts. Journal of Food Composition and Analysis, 2, 338-349.

5. Dimić, E, Vujasinović, V., Radočaj, O., Pastor, O., (2012). Characteristics of blackberry and raspberry seeds and oils. Acta Periodica Technologica, 43, 1-9.

6. Gođevac, D., Tešević, V., Vajs, V., Milosavljević, S., Stanković, M. (2009). Antioxidant properties of raspberry seed extracts on micronucleus distribution in peripheral blood lymphocytes. Food and Chemical Toxicology, 47, 2853-2859.

7. Halliwell, B. (1999). Establishing the significance and optimal intake of dietary antioxidants: The biomarker concept. $\mathrm{Nu}$ trition Reviews, 57, 104-113. 
8. Kähkönen, M.P., Hopia, A.I., Heinonen, M. (2001). Berry phenolics and their antioxidant activity, Journal of Agriculture and Food Chemistry, 49, 4076-4082.

9. Khanduja, K.L., Gandhi, R.K., Pathania, V., Syal, N. (1999). Prevention of Nnitrosodiethylamine- induced lung tumorigenesis by ellagic acid and quercetin in mice. Food and Chemical Toxicology, 37, 313-318.

10. Li, B., Harich, K., Wegiel, L., Taylor, L.S., Edgar, K.J. (2013). Stability and solubility enhancement of ellagic acid in cellulose ester solid dispersions, Carbohydrate Polymers, 92, 1443- 1450.

11. Mates, J.M., Sanches-Jimenes, F. (1999). Antioxidant enzymes and their implications in pathophysiologic processes. Frontiers in Bioscience, 4, 339-345.

12. Mitscher, L.A., Telikepalli, H., McGhee, E., Shankel, D.M. (1996). Natural antimutagenic agents. Mutation Research, 350, 143-152.

13. Mullen, W., Stewart, A.J., Lean, M.E.J., Gardner, P., Duthie, G.G:, Crozier, A., (2002). Effect of freezing and storage on the phenolics, ellagitannins, flavonoids, and antioxidant capacity of red raspberries, Journal of Agriculture and Food Chemistry, 50, 5197-5201.

14. Nile, S.H., Park, S.V. (2014). Edible berries: Review on bioactive components and their effect on human health. Nutrition, 30, 134-144.

15. Puupponen-Pimiä, R., Nohynek, L., Meier, C., Kähkönen, M., Heinonen, M., Hopia, A., Oksman-Caldentey, K.M. (2001). Antimicrobial properties of phenolic compounds from berries. Journal of Applied Microbiology, 90, 494-507.

16. Rice - Evans, C. A., Miller, N. J., Paganga, G. (1997). Antioxidant properties of phenolic compounds. Trends in Plant Science, 2, 152- 159.

17. Rios de Souza, V., Pereira, P.A.P., Teodoro da Silva, T.L., Lima, L.C.O., Pio, R., Queiroz, F. (2014). Determination of the bioactive compounds, antioxidant activity and chemical composition of Brazilian blackberry, red raspberry, strawberry, blueberry and sweet cherry fruits. Food Chemistry, 156, 362-368.

18. Seeram, N.P., Adams, L.S., Zhang, Y., Lee, R., Sand, D., Scheuller, H.S., Heber, D. (2006). Blackberry, black raspberry, blueberry, cranberry, red raspberry, and strawberry extracts inhibit growth and stimulate apoptosis of human cancer cells in vitro. Journal of Agriculture and Food Chemistry, 54, 9329-9339.

19. Singh, K., Khanna, A.K., Chander, R. (1999). Hepatoprotective effect of ellagic acid against carbon tetrachloride induced hepatotoxicity in rats. Indian Journal of Experimental Biology, 37, 1025-1026.

20. Singh, J., Dartois, A., Kaur, L. (2010). Starch digestability in food matrix: a review. Trends in Food Science and Technology, 21, 168-180.

21. Soni, K.B., Lahiri, M., Chackradeo, P., Bhide, S.V., Kuttan, R. (1997). Protective effect of food additives on aflatoxininduced mutagenicity and hepatocarcinogenicity. Cancer Letters, 115, 129-133.

22. Szajdek, A., Borowska, E.J. (2008). Bioactive compounds and health-promoting properties of berry fruits: A review. Plant Foods for Human Nutrition, 63, 147-156.

23. Teel, R.W. (1986). Ellagic acid binding to DNA as possible mechanism for its antimutagenic and anticarcinogenic action. Cancer Letters, 30, 329-336.

24. Valdimarsdottir, U., Helgason, A. R., Furst, C.J., Adolfsson, J., Steineck, G. (2003). Long-term efects of widowhood after terminal cancer: a Swedish nationwide follow-up. Scandinavian Journal of Public Health, 31, 31-36.

25. Van Hoed, V., Barbouche, I., De Clercq, N., Dewettnick, K., Slah, M., Leber, E., Verhé, R. (2011). Influence of filtering of cold pressed berry seed oils on their antioxidant profile and quality characterristics. Food Chemistry, 127, 1848-1855.

26. Wang, S.Y., Lin, H.S. (2000). Antioxidant activity in fruits and leaves of blackberry, raspberry, and strawberry varies with cultivar and developmental stage. Journal of Agriculture and Food Chemistry, 48, 140-146.

27. Zafrilla, P., Ferreres, F., Tomas-Barberan, F.A. (2001). Effect of processing and storage on the antioxidant ellagic acid derivatives and flavonoids of red raspberry (Rubus idaeus) jams. Journal of Agriculture and Food Chemistry, 49, 36513655.

28. Zhang, Z., Hamilton, S.M., Stewart, C., Strother, A., Teel,, R.W. (1993). Inhibition of liver microsomal cytochrome P450 activity and metabolism of the tobaccospecific nitrosamine NNK by capsaicin and ellagic acid. Anticancer Research, 13 (6A), 2341-2346.22. 


\section{УТИЦАЈ РАЗЛИЧИТИХ ТЕМПЕРАТУРА ЕКСТРУДИРАЊА НА СТАБИЛНОСТ ЕЛАГИНСКЕ КИСЕЛИНЕ ИЗ СЕМЕНА МАЛИНЕ}

Бошко Д. Марић, Марија И. Бодрожа Соларов, Небојша М. Илић, Јована С. Којић, Јелена А. Круљ

Универзитет у Новом Саду, Научни институт за прехрамбене технологије у Новом Саду,
21000 Нови Сад, Булевар цара Лазара бр. 1, Србија

Сажетак: Производња прехрамбених производа од малине оставља велику количину семена које се третира као нуспроизвод или отпад. Семе малине је богат извор елагинске киселине. Око $88 \%$ укупног садржаја елагинске киселине у малинама се налази у семену.

Овај рад се бави истраживањем ефеката процеса екструзије на различитим температурама на садржај елагинске киселине у семену малина сорте "Willamette". Екструдирање је изведено на једнопужном лабораторијском екструдеру и на три температурна режима: $140{ }^{\circ} \mathrm{C}, 160{ }^{\circ} \mathrm{C}$ и 200 ${ }^{\circ} \mathrm{C}$. Аналитичка техника HPLC/DAD је коришћена за одређивање и квантификацију садржаја елагинске киселине у екструдираним узорцима. Квантификација елагинске киселине одређена је помоћу калибрационе криве добијене од аналитичког стандарда елагинске киселине.

Одређен је садржај елагинске киселине у узорку семена малине сорте „Willamete“ и он износи $286,54 \mu \mathrm{g} / \mathrm{g}$. Ефеекти различитих температура екструдирања на стабилност елагинске киселине из семена малине сорте „Willamete“ нису направили значајну разлику у садржају елагинске киселине, што семе малине сорте „Willamete“ чини погодним за производњу хране на високим температурама.

Кључне речи: екструдирање, семе малине, елагинска киселина, кукурузна крупица, прозиводи са додатом вредношћу

Received: 25 April 2018

Received in revised form: 18 May 2018

Accepted: 28 May 2018 